\title{
Remote Sensing and GIS analysis for demarcation of coastal hazard line along the highly eroding Krishna-Godavari delta front
}

\author{
Akhil Kallepalli ${ }^{\mathrm{a}}$, Kakani Nageswara Rao ${ }^{\mathrm{b}}$, and David B James ${ }^{\mathrm{a}}$ \\ ${ }^{a}$ Centre for Electronic Warfare, Information and Cyber, Cranfield University, Defence \\ Academy of the United Kingdom, Shrivenham, United Kingdom SN6 8LA \\ ${ }^{\mathrm{b}}$ Department of Geo-Engineering, Andhra University, Visakhapatnam
}

\begin{abstract}
Coastal regions, especially river deltas are highly resourceful and hence densely populated; but these extremely low-lying lands are vulnerable to rising sea levels due to global warming threatening the life and property in these regions. Recent IPCC (2013) predictions of 26-82cm global sea level rise are now considered conservative as subsequent investigations such as by Met Office, UK indicated a vertical rise of about $190 \mathrm{~cm}$, which would displace $10 \%$ of the world's population living within 10 meters above the sea level. Therefore, predictive models showing the hazard line are necessary for efficient coastal zone management. Remote sensing and GIS technologies form the mainstay of such predictive models on coastal retreat and inundation to future sea-level rise. This study is an attempt to estimate the varying trends along the Krishna-Godavari $(\mathrm{K}-\mathrm{G})$ delta region. Detailed maps showing various coastal landforms in the K-G delta region were prepared using the IRS-P6 LISS 3 images. The rate of shoreline shift during a 31-year period along different sectors of the $330 \mathrm{~km}$ long K-G delta coast was estimated using Landsat-2 and IRS-P6 LISS 3 images between 1977 and 2008. With reference to a selected baseline from along an inland position, End Point Rate (EPR), Shoreline Change Envelope (SCE) and Net Shoreline Movement (NSM) were calculated, using a GIS-based Digital Shoreline Analysis System (DSAS). The results showed that the shoreline migrated landward up to a maximum distance of $3.13 \mathrm{~km}$ resulting in a net loss of about $42.10 \mathrm{~km}^{2}$ area during this 31-year period. Further, considering the nature of landforms and EPR, the future hazard line is predicted for the area, which also indicated a net erosion of about $57.68 \mathrm{~km}^{2}$ along the K-G delta coast by 2050 $\mathrm{AD}$.
\end{abstract}

Keywords: Shoreline Change, Sea Level Rise, Hazard Line Demarcation, Coastal Zone Management, Coastal Erosion, Global Warming

\section{INTRODUCTION}

Climatic change, along with increased generation and concentration of carbon dioxide and consequent global warming impacts are ringing alarm bells for appropriate coastal zone management today, creating a sudden emphasis over the need to control the changes that are disturbing the delicate balance upon which the life forms of this planet survive. Continued sea level rise is heavily dependent on the sustenance of these emissions in the years to come [1]. Locally, increases could be greater, depending on land subsidence factors [2]. The global warming trend over the past 50 years was reported by the Intergovernmental Panel on Climate Change (IPCC) to be in the order of $0.13^{\circ} \mathrm{C}$ per decade [3]. Global sea level has been observed to rise at a rate of $1.8 \mathrm{~mm} /$ year over the period of 1961-2003 and about 3.1mm/year over the period of 1993-2003 as a response to global temperature rise [4]. Although IPCC 2007 estimated a rise of about $59 \mathrm{~cm}$, subsequent semi-empirical models using the past sea levels and temperature data suggested a sea level rise of greater than $1 \mathrm{~m}$ by 2100 A.D. [5]. More recent estimates by the IPCC (2013) [1] have classified the possibility of increase greater than that predicted in AR4 (IPCC 2007) as very likely.

Address all correspondence to

Akhil Kallepalli, E-mail: a.kallepalli@cranfield.ac.uk

Earth Resources and Environmental Remote Sensing/GIS Applications VII, edited by Ulrich Michel, Karsten Schulz, Manfred Ehlers, Konstantinos G. Nikolakopoulos, Daniel Civco, Proc. of SPIE Vol. 10005, 1000507 (C) 2016 SPIE $\cdot$ CCC code: 0277-786X/16/\$18 · doi: 10.1117/12.2239485 
The immediate implication of increased global warming, due to variation in temperatures $[1,6]$, amongst other causes, directly relates to rise of sea level. Paleo-sea level from periods warmer than current have evidently been $5 \mathrm{~m}$ higher [1], indicative of the impact of disturbance on the balance of the quantity of water on the Earth. Locally, increases could be still greater, depending on the land subsidence factors [2]. The effects of worldwide sea level rise will be spatially non-uniform, for several reasons. Firstly, global sea level rise is superimposed on local vertical crustal movement (e.g. an area where land is rising is at less risk when compared to regions that are subsiding). Secondly, characteristics of any shoreline depend on the interaction of the sea with the various landforms of the coast [2] whether it is lithological, structural or any other characteristic that has an impact on the rate of sea level rise, locally. Therefore, it is imperative that studies should be made in order to assess the relative vulnerability of different sectors of the coast, taking into consideration the various features and phenomena that characterize the coastal sector in question. Many attempts [7-9] have been made in this direction from different parts of the world using different methods. The present study is an attempt to make an assessment of the vulnerability of the Krishna-Godavari delta coast along the east coast of India using the Digital Shoreline Analysis System (DSAS) [10].

\section{STUDY AREA}

The twin delta system of Krishna and Godavari rivers, draining the catchment into the Bay of Bengal, is shown in Figure 1. Geographically, the Godavari delta front is $170 \mathrm{~km}$, compared to $140 \mathrm{~km}$ of the Krishna delta. These deltas and the $26 \mathrm{~km}$ inter-delta region characterize the study area for this work.

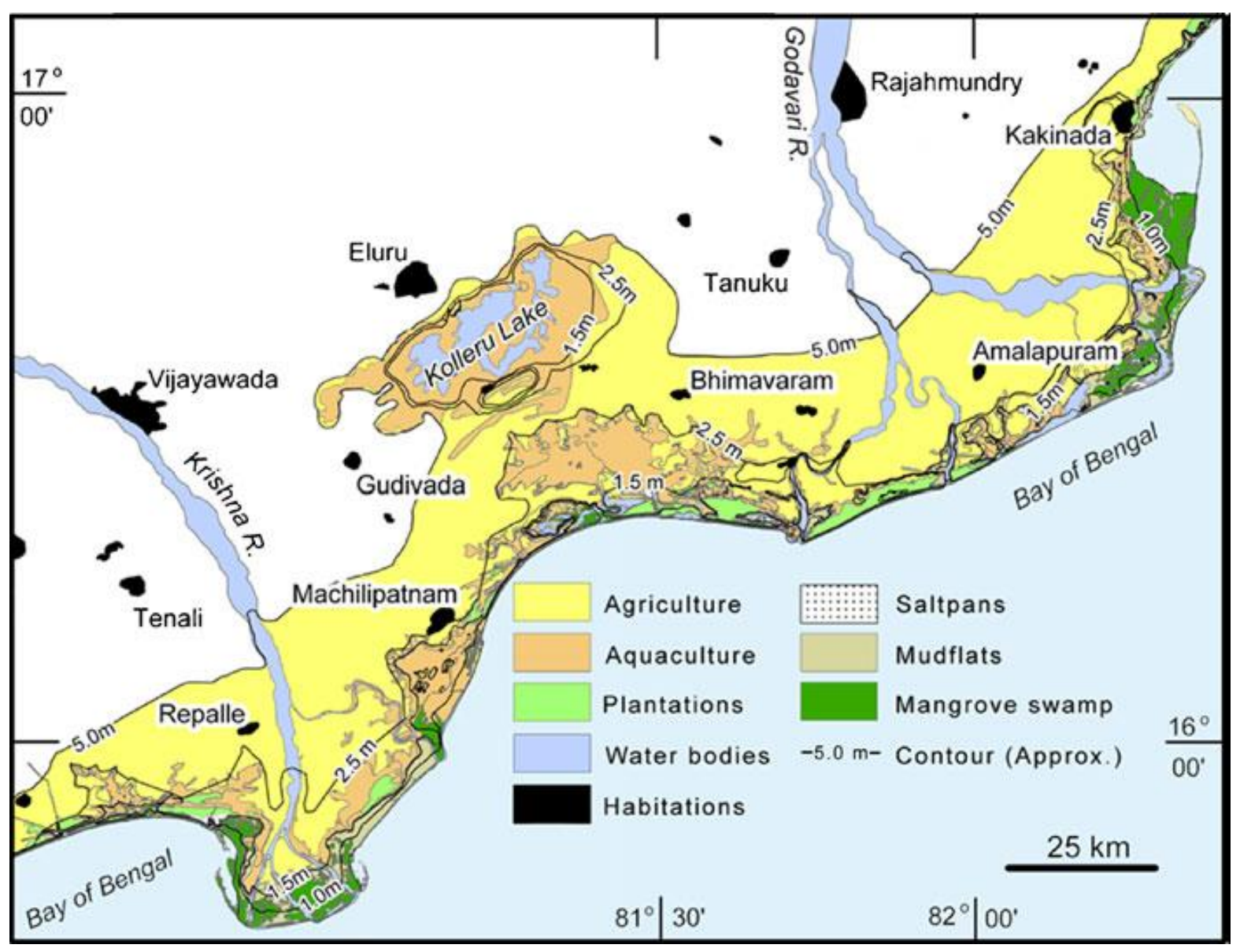

Figure 1. Land Use/Land Cover of study area, depicting the features within the 5m contour [11]. 


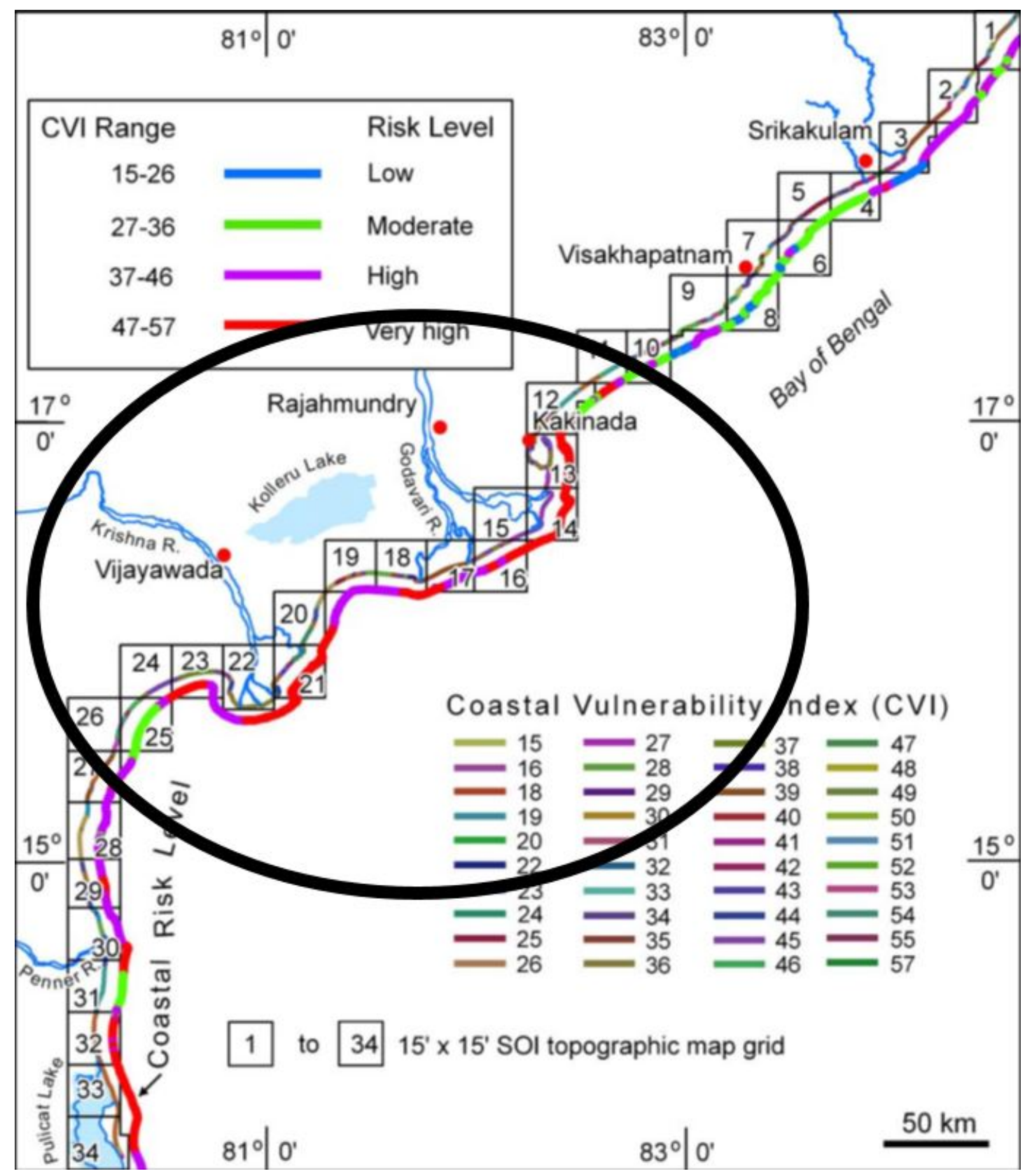

Figure 2. Coastal Vulnerability map [12] indicating varying vulnerabilities along the study area.

The Godavari and Krishna rivers originate in the eastern slopes of the Western Ghats and flow across the peninsula, while joined by multiple tributaries along the way, to drain into the Bay of Bengal. This semi-arid region receives an average rainfall of $1100 \mathrm{~mm}$ in the Godavari Delta [13] and 840mm in the Krishna Delta [14] and the rivers cumulatively drain a catchment equal to the area of India. Built into a peri-cratonic basin, both the rivers form a contiguous and complex delta system which is known as the Krishna-Godavari (K-G) sedimentary basin $[15,16]$. Distinction between the two deltas is done by using their paleo-river channels, the farthest boundaries of which define the delta basin. Thus, the modern Krishna-Godavari twin delta complex $\left(12,700 \mathrm{~km}^{2}\right.$ in area) is composed of the Godavari $\left(5,200 \mathrm{~km}^{2}\right.$ in area) and Krishna $\left(4,800 \mathrm{~km}^{2}\right.$ in area) deltas and an inter-delta plain of $2,700 \mathrm{~km}^{2}$ area which is significantly influenced by the sediment flow into the deltas and the 
transport of these along the shore. The inter-delta plain is characterized by a series of lagoons like the Kolleru Lake (a former lagoon turned into a freshwater lake, Figure 1) and Goguleru Creek (present lagoon) separated by several beach ridges $[17,18]$.

The region experiences a marine environment influenced by relatively low-energy tidal conditions (spring tide range is $<1.5 \mathrm{~m}$ ) and low to moderate wave conditions (significant wave height is $<2 \mathrm{~m}$ ) [12]. However, placed in the Bay of Bengal region that experiences frequent cyclones, this delta is prone to severe cyclonic activity accompanied by strong waves and storm surges which reach many kilometres inland, because of its extremely low lying nature and gentle gradient. These densely populated deltas have an average population of 729 persons per square kilometre $\left(\mathrm{km}^{2}\right)$. The great loss of life and damage to property in the Godavari delta region caused by the 1990 and 1996 storm surges are evidence to the low-lying and populated nature of region.

It is also important to note the geomorphology of the coastline, as the features that fringe the study area define the erosion and deposition patterns and trends. From previous studies [2,12], it can be understood, for example, that rocky terrains tend to obstruct erosion, while mudflats and the like tend to erode comparatively easily. The geomorphology of the study area [12] was considered in the sections of hazard line generation, after the statistical calculation of shoreline changes. The shoreline has various degrees of vulnerability. As mentioned before, regions of strong lithology like Visakhapatnam (Figure 2) are under lesser risk of impact due to the presence of rocky terrain, while regions that are relatively flat and have lesser obstruction to the oncoming sea impacts are at a higher risk, like the $\mathrm{K}-\mathrm{G}$ delta basin, the study area in this case. When considering the impacts of storm surges, which may be sudden and of short duration, or slow and long spanning erosion of deltas due to sea level rise, the $\mathrm{K}-\mathrm{G}$ delta region is a vulnerable region with the majority of its area being considered to be at 'high risk' [12].

\section{METHOD OF STUDY}

The present study was carried out with the tools of GIS (ArcGIS) and image processing, using multi-date satellite products. Figure 3 illustrates the methodology adopted for this study which involves geo-referencing of the images, GIS extraction of shorelines, construction of a reference line (baseline) to estimate the movement of the shoreline, estimation of change statistics and estimation of the hazard line on the basis of rate of change and physical coastal conditions. Georeferenced satellite imagery (Table 1) form the base data for extraction of the temporal configuration of the Krishna-Godavari delta front shoreline during the past four decades from 1977 to 2008.

Table 1. Satellite data used in the present study

\begin{tabular}{|c|c|}
\hline Dataset Information & Date of Imagery \\
\hline Landsat MSS & 01-May-1977 \\
\hline Landsat TM & $10-$ Nov-1990 \\
\hline Landsat ETM+ & $28-$ Oct-2000 \\
\hline IRS-P6 LISS III & $13-$ Dec-2004 \\
\hline IRS-P6 LISS III & 25-Jan-2006 \\
\hline IRS-P6 LISS III & 03-Mar-2008 \\
\hline
\end{tabular}

The workflow of estimation of the hazard line begins with the referencing of the datasets to a common datum and projection system. In the absence of a common projection system, the estimations of the shoreline would not be exact and accurate. Chosen in this case are UTM-projection and WGS84-datum. The imagery datasets are referenced to this system before GIS demarcation of individual shorelines. The multi-spectral datasets are considered as FCC (False Colour Composites) for demarcation of the shorelines, as the usage of the infrared bands allows relatively easier distinction of water boundaries. ArcGIS is used to extract individual shorelines, and saved as shapefiles. The 'Date' data type must be saved in the shapefile (line vector data), as this is needed for the change statistics that Digital Shoreline Analysis System (DSAS) [10] would utilise. DSAS, the change 


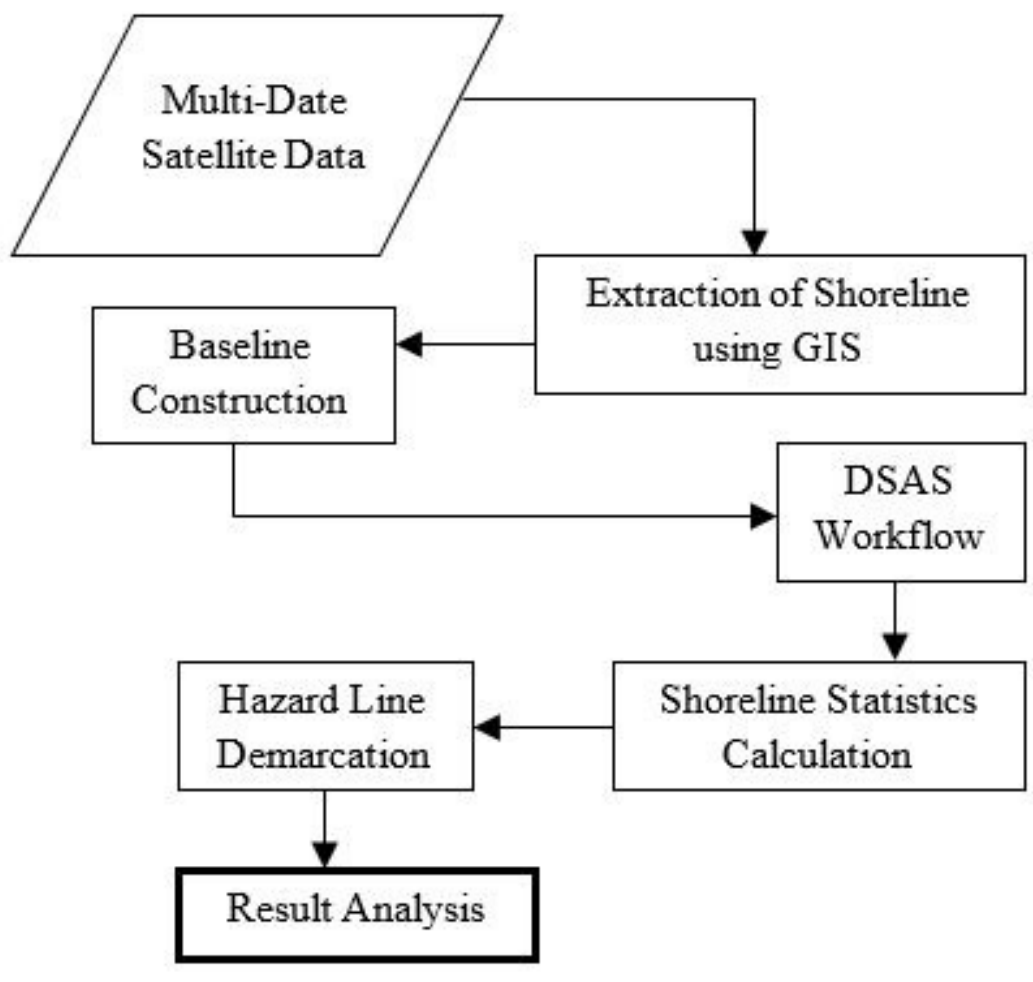

Figure 3. Methodology Flowchart

detection application developed by USGS, is an add-on product to ArcGIS which constructs transects from a predefined baseline for estimating shoreline changes.

DSAS allows the construction of an arbitrary baseline in the landward direction of the concerned water body. In order to quantify the movement of the shoreline, with respect to the standard baseline, transects are constructed (Figure 4). With due consideration of past change patterns in the region [11], the geo-referenced baseline was established $2.5 \mathrm{~km}$ landward from the shoreline position in 1977 and used for every combination of consecutive datasets.

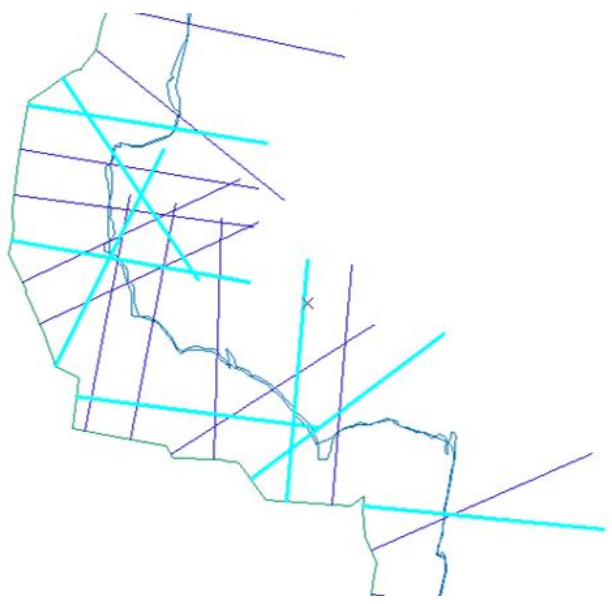

Figure 4. Erroneous orientation of transects is possible, thus prompting a verification before calculation of statistics. The orientation and the density of the transects along the shoreline must be verified to be optimal 
The measuring elements of the DSAS workflow involve the construction and spacing of transects. The decision of number of transects is task-specific and must be analysed before calculation of change statistics. If the number of transects are low, the regions encountering high erosion or deposition may not have an acceptable number of transects passing through them, thereby resulting in the loss of valuable statistics of change. If the number of transects are excessive, then the density of transects through each region might be different, leading to over or under-estimation of information. Therefore, for this study a combination of optimal number of transects and manual validation of spacing and density of transects is performed. Simple transects are cast along the baseline at 2000 meters spacing and 8000 meters in length. The length of transects is not a value of concern as the change along the region of intersection is calculated, wherein the length of transect will not play any role.

Due to the irregular nature of a shoreline, the transects constructed from the baseline are of different orientations. Erroneously oriented transects (Figure 4) are corrected manually before the calculation of shoreline change statistics. This ensures that the study area has a distributed transect presence, after the automated creation by DSAS.

Shoreline statistics are pivotal in understanding the movement of the shoreline in a given time interval. This movement is an indication of the direction of change in this region. Erosion and deposition are the two main shoreline altering factors of coasts. Transects previously generated are used to generate the following statistics along the coasts of Krishna-Godavari Delta and inter-delta region, along each transect in order to estimate a trend.

1. Net Shoreline Movement (NSM) reports the distance, but not the rate. The NSM statistic is associated with the dates. It reports the distance between the oldest and youngest shoreline, with positive or negative symbols indicative of deposition or erosion.

Net Shoreline Movement $=$ Distance between oldest and youngest shorelines

2. End Point Rate (EPR) is calculated by dividing the distance of shoreline movement by the time elapsed between the oldest and most recent shoreline. The major advantage of the EPR is the ease of computation and minimal requirement of 2 shoreline dates.

End Point Rate = (Distance in meters) / (time between oldest and most recent shoreline)

While the knowledge of change is established statistically, it is vital to account for the encountered landforms on the coastline. A trend of high erosion in a location where the morphology is that of a marshland would change if it encountered a rocky terrain within the time frame of this study. The hazard line in this study is to be estimated to 2050, and under this time frame, the erosion trend encounters a single morphology only. In order to estimate their impacts, a linear relationship between the rate of erosion/deposition is assumed with the rank of the terrain. A geomorphological feature like rocky cliffs along the coastline would be attributed a rank of 1 , while highly eroding and unstable features like mudflats would be attributed to a rank of 5 [12]. The corresponding ranks were given to the geomorphological features and the erosion and deposition patterns were extrapolated along these features, with their respective weights (Table 2). It must be noted that these weights are study area specific, and with a change of study area, an investigation of coastal morphology is vital.

Table 2. Weights of Coastal Geomorphology, and their impacts on the erosion/deposition rates [12]

\begin{tabular}{|c|c|c|c|c|c|}
\hline $\begin{array}{c}\text { Coastal } \\
\text { Geomorphology }\end{array}$ & $\begin{array}{c}\text { Rocky } \\
\text { Coasts }\end{array}$ & $\begin{array}{c}\text { Indented } \\
\text { Coasts }\end{array}$ & $\begin{array}{c}\text { Beach Ridges, } \\
\text { Vegetated Dunes }\end{array}$ & $\begin{array}{c}\text { Low Dunes, } \\
\text { Estuaries and } \\
\text { Lagoons }\end{array}$ & $\begin{array}{c}\text { Mudflats, } \\
\text { Mangroves, Beaches, } \\
\text { Barriers/Spits }\end{array}$ \\
\hline Rank & 1 & 2 & 3 & 4 & 5 \\
\hline $\begin{array}{c}\text { Degree of } \\
\text { Influence }\end{array}$ & $20 \%$ & $40 \%$ & $60 \%$ & $80 \%$ & $100 \%$ \\
\hline
\end{tabular}

The shoreline is divided into sectors of erosion and deposition depending on the change statistics. Multiplying the degree of influence of each encountered geomorphology along the coast, the movement of the coastline was 
extrapolated to 2050 and the hazard line (shoreline at a future date) is drawn. Using a polygon-based area calculation, the loss and gain of land, due to erosion and deposition, along the $\mathrm{K}-\mathrm{G}$ delta can be calculated.

\section{RESULTS}

The shoreline change statistics calculated are Net Shoreline Movement (NSM) and End Point Rate (EPR). It is to be noted that NSM gives the amount of change with respect to time and EPR calculates the rate of change. In the context of the current study where the hazard line demarcation and the estimation of change to a future date are being examined, EPR stands out as the most important. Therefore, further analysis (trend investigation and hazard line construction) are done using EPR. The statistics, along all the transects cumulatively, are presented in Table 3.

Table 3. End Point Rate statistics for 1977-2008

\begin{tabular}{|c|c|c|c|c|c|c|c|c|c|}
\hline Period & \multicolumn{3}{|c|}{ Krishna Delta } & \multicolumn{3}{c|}{ Inter-Delta Region } & \multicolumn{3}{c|}{ Godavari Delta } \\
\hline & Min & Max & Net & Min & Max & Net & Min & Max & Net \\
\hline $1977-1990$ & -62.34 & 32.07 & $\mathbf{- 1 3 . 9 9}$ & -18.4 & 28.85 & $\mathbf{- 2 . 4 2}$ & -148.7 & 77.25 & $\mathbf{- 3 . 8 5}$ \\
\hline $1990-2000$ & -41.1 & 166.26 & $\mathbf{7 . 2 1}$ & -27.52 & 48.79 & $\mathbf{2 . 7 3}$ & -107.6 & 35.77 & $\mathbf{- 0 . 3 3}$ \\
\hline $2000-2004$ & -154.1 & 132.74 & $\mathbf{1 2 . 2 3}$ & 34.84 & 89.05 & $\mathbf{6 0 . 2 6}$ & 60.03 & 134.81 & $\mathbf{4 5 . 2 5}$ \\
\hline $2004-2006$ & -502.5 & 411.1 & $\mathbf{- 1 2 2 . 5}$ & -122.5 & 144.37 & $\mathbf{- 2 3 . 5 3}$ & -389.4 & 979.2 & $\mathbf{- 4 0 . 5 8}$ \\
\hline $2006-2008$ & -234.6 & 189.49 & $\mathbf{5 0 . 4 5}$ & -74.18 & 64.61 & $\mathbf{- 6 . 1 6}$ & -505.7 & 219.4 & $\mathbf{3 0 . 4 9}$ \\
\hline Total (1977-2008) & $\mathbf{- 3 2 . 0 6}$ & $\mathbf{8 7 . 6 2}$ & $\mathbf{- 1 . 7 2 6}$ & $\mathbf{- 2 5 . 5 3}$ & $\mathbf{2 6 . 8 7}$ & $\mathbf{1 . 7 5}$ & $\mathbf{- 1 0 1 . 9}$ & $\mathbf{3 9 . 0 7}$ & $\mathbf{- 3 . 3 2}$ \\
\hline
\end{tabular}

The nomenclature of the table statistics: the Minimum column is indicative of the least occurrence of the phenomenon (erosion or deposition), while the Maximum indicates the opposite. The negative sign (-) indicates erosion while the positive $(+)$ indicates deposition, with net EPR illustrated along all transects in the entire study area. Although EPR measurement is at individual locations, it is a dependable source of information as it is estimated from well distributed transects in all sectors along the study area.

Periodical analysis of trends along the transects indicates the variation of erosion and deposition in different sectors of the study area. The entire region has experienced a significant amount of erosion during the 2004-2006 period, due to the tsunami of December, 2004. The imagery of 2004 (before the tsunami) and the subsequent dataset of 2006 provide an insight into the localised impact of the tsunami. In summary, however, it is noted that the Krishna and Godavari deltas are impacted severely by the forces of the sea, and the shoreline movement is erosion and incursion-dominant. Deposition in the inter-delta plain is attributed to along-shore sediment movement, and to the "bay-like" configuration of the delta combination. 


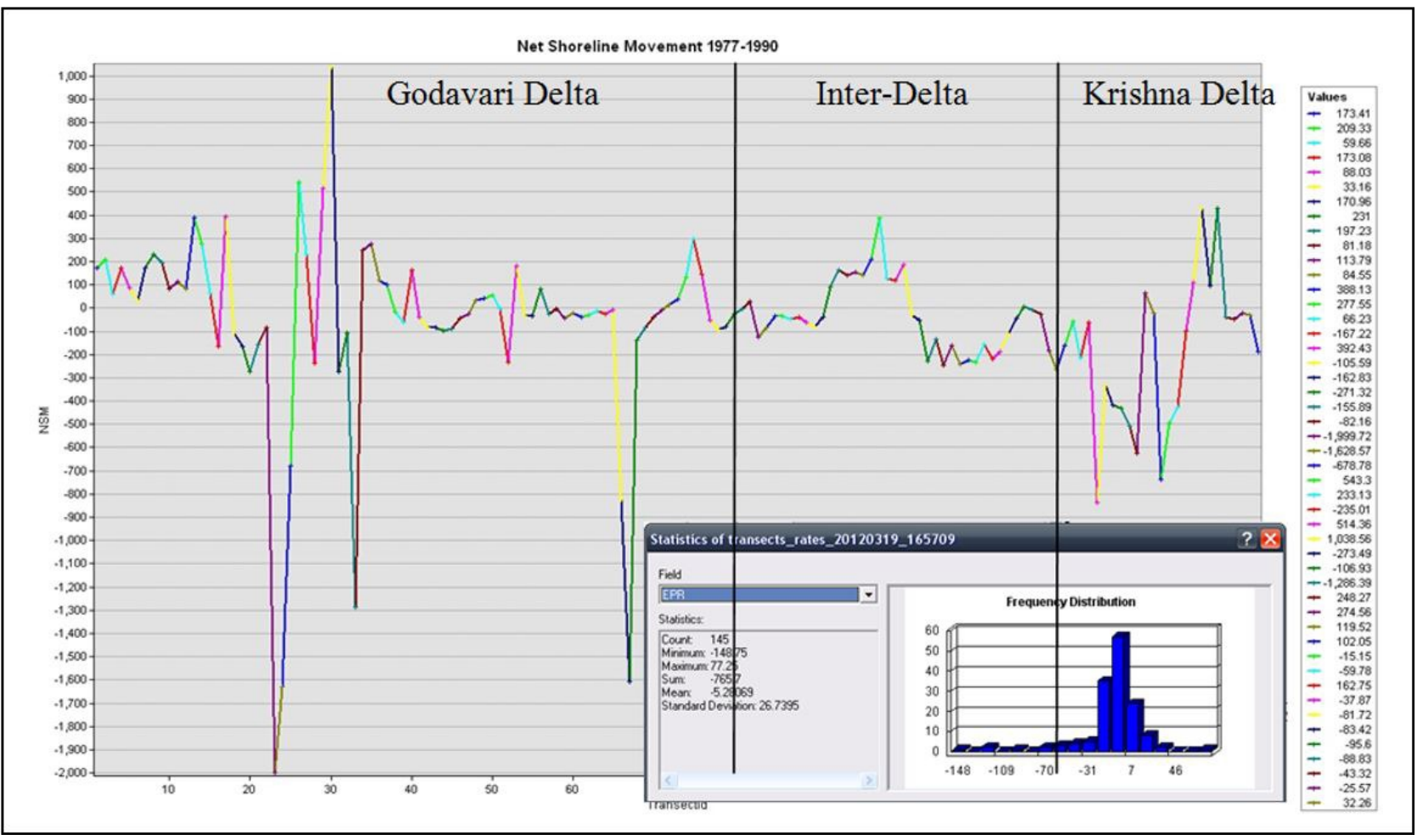

Figure 5. NSM/EPR Trend of Study Area in the period 1977-1990

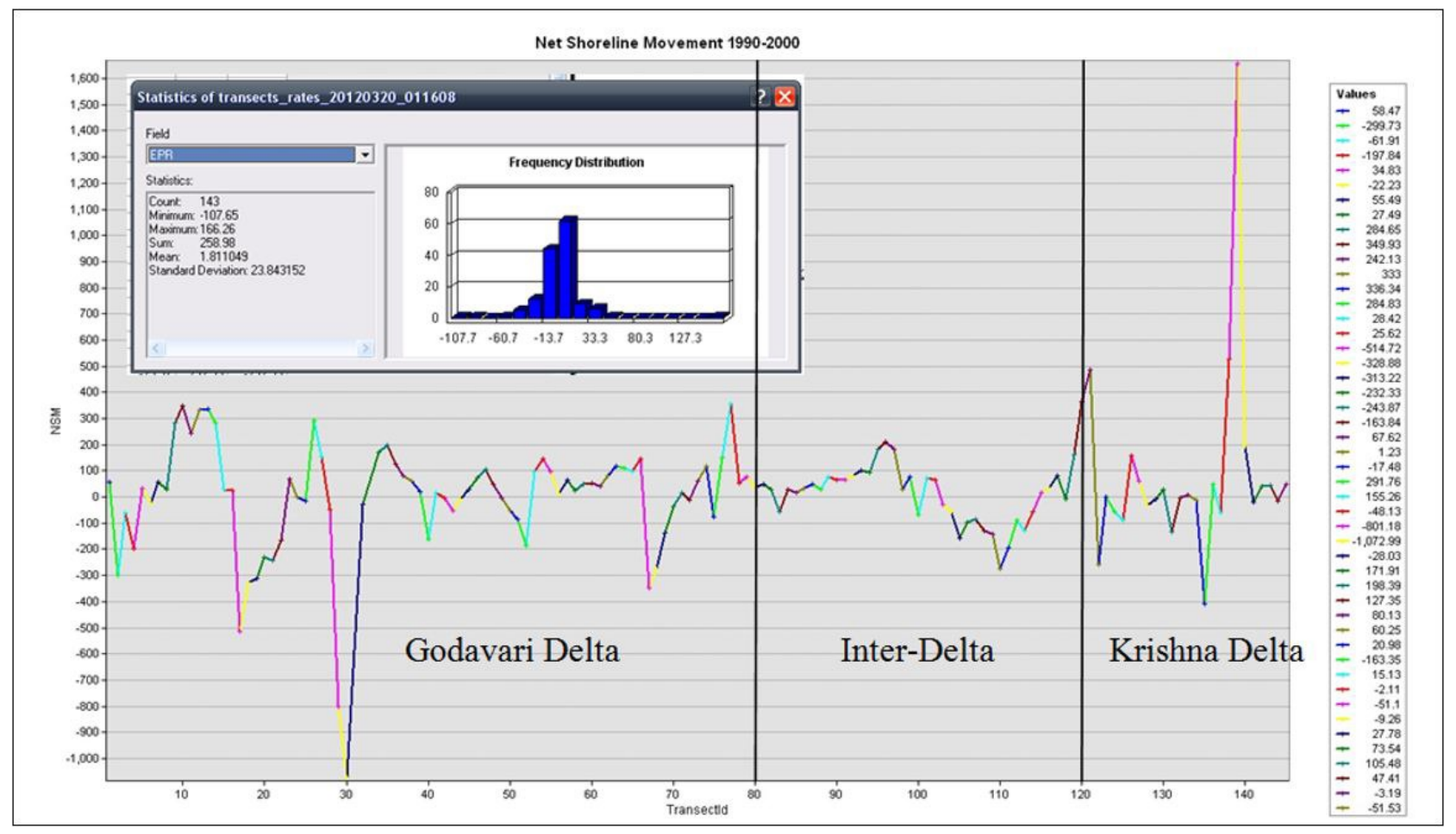

Figure 6. NSM/EPR Trend of Study Area in the period 1990-2000 


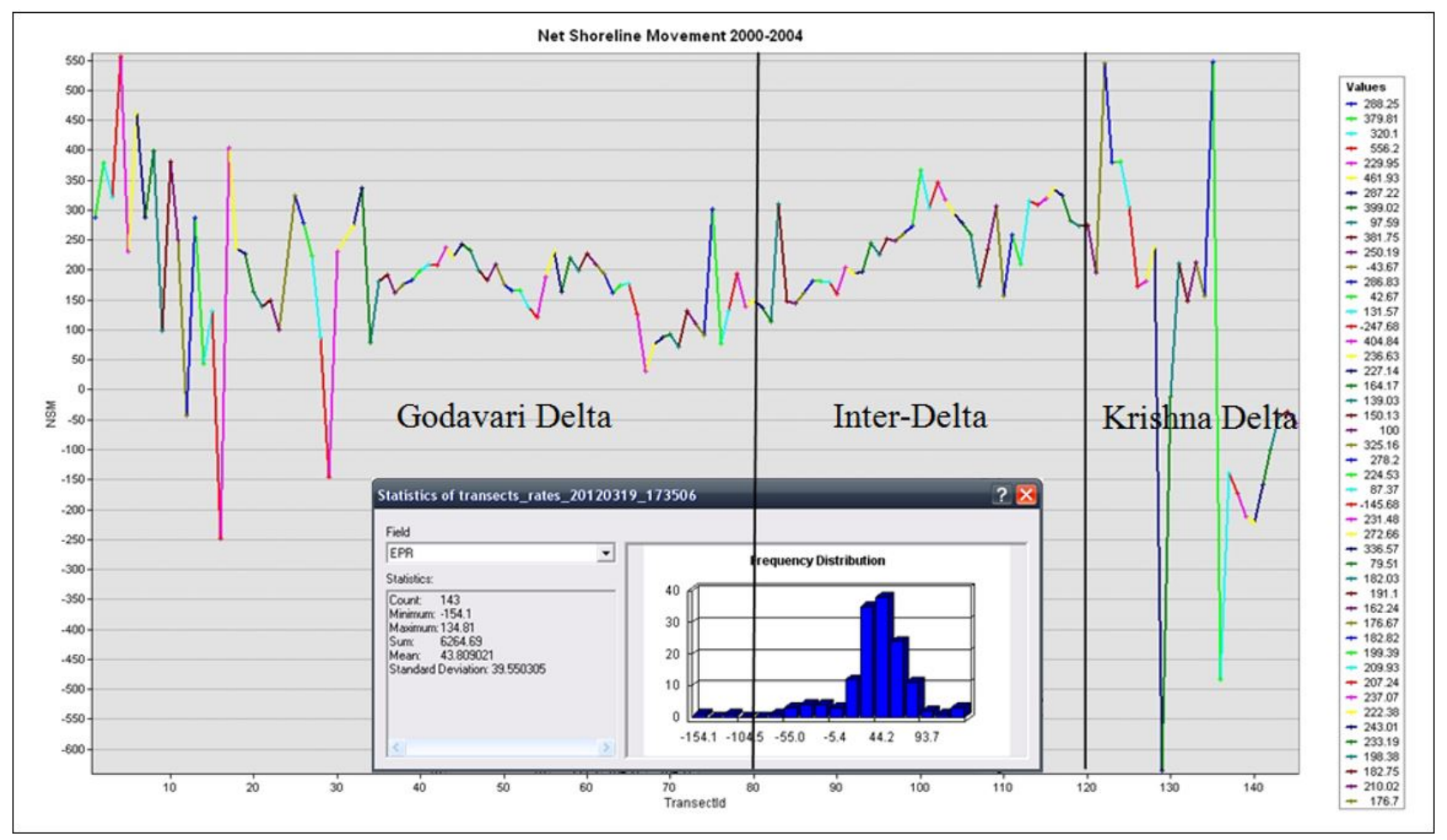

Figure 7. NSM/EPR Trend of Study Area in the period 2000-2004

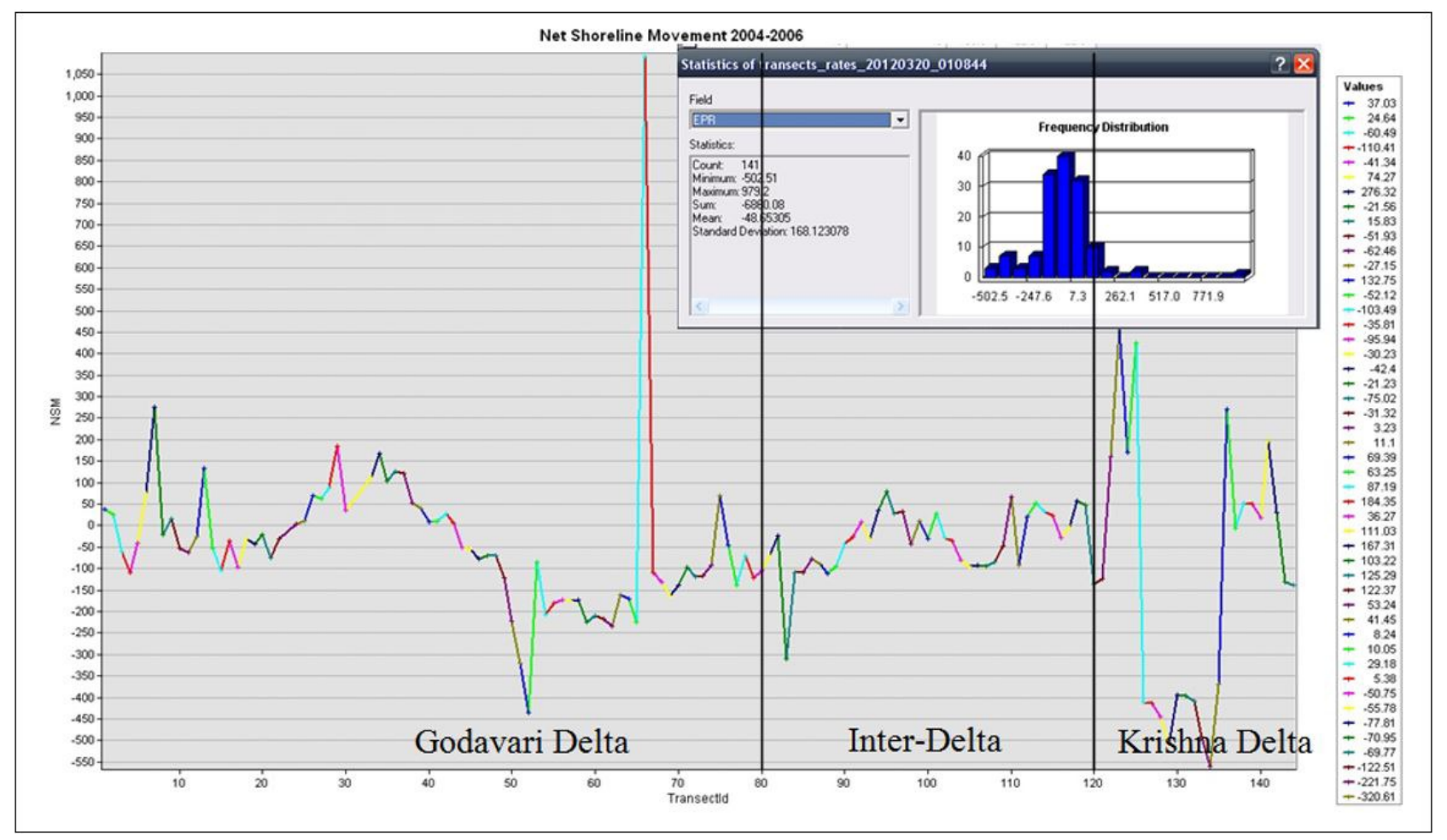

Figure 8. NSM/EPR Trend of Study Area in the period 2004-2006 


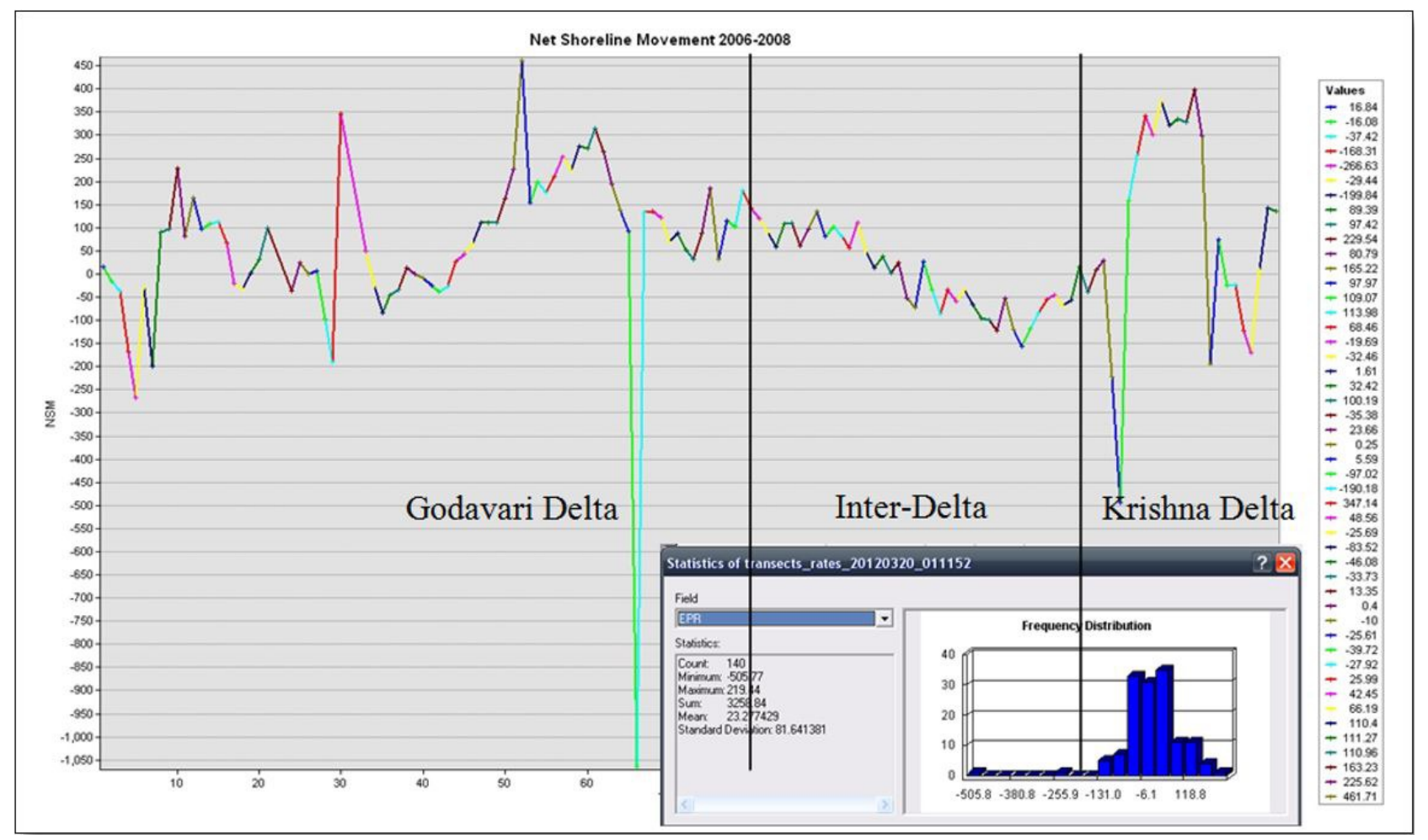

Figure 9. NSM/EPR Trend of Study Area in the period 2006-2008

During the period of 1977-1990, the region predominantly experienced erosion. The Net Shoreline Movement was landward (Figure 5, Table 3), indicating erosion in all sectors, including an erosion rate of $2.42 \mathrm{~m}$ in the inter-delta region. The decade of 1990-2000 and through to 2004 experienced localised erosion in the Godavari delta, only to the tune of $0.33 \mathrm{~m}$ (Table 3 ). The frequency distributions of the transect-calculated EPR also shifts towards the deposition rates (Figure 6,7). Net erosion is observed in the 2004-2006 period, attributed to the increased erosion trends being coupled with the impacts of the tsunami of 2004 (Figure 8). The overall trend in the following two-year period shows net deposition in the deltaic regions, but erosion only in the inter-delta region (Figure 9). The statistics presented in each of the mentioned figures showing the NSM distribution describe the overall trend of the region, along all transects. This assists in making interpretations regarding the impact of the sea on the whole study area, such as the highest erosion experienced by the region in 2004-2006 due to the impact of the tsunami.

Considering the occurrence of natural phenomena, the overall trend in the $\mathrm{K}-\mathrm{G}$ delta basin, including the inter-delta region, implies a trend of erosion, greater than deposition. The overall implication of microscopic changes in shorter time-frames can be assessed by observing the shoreline changes for the first and final datasets, i.e. 1977 and 2008. The assessment (Figure 10) indicates a cumulative erosion rate to the tune of $1.726 \mathrm{~m} /$ year in the Krishna Delta, $3.32 \mathrm{~m} /$ year in the Godavari Delta and a deposition of $1.75 \mathrm{~m} /$ year in the inter-delta plain (Table 3). 


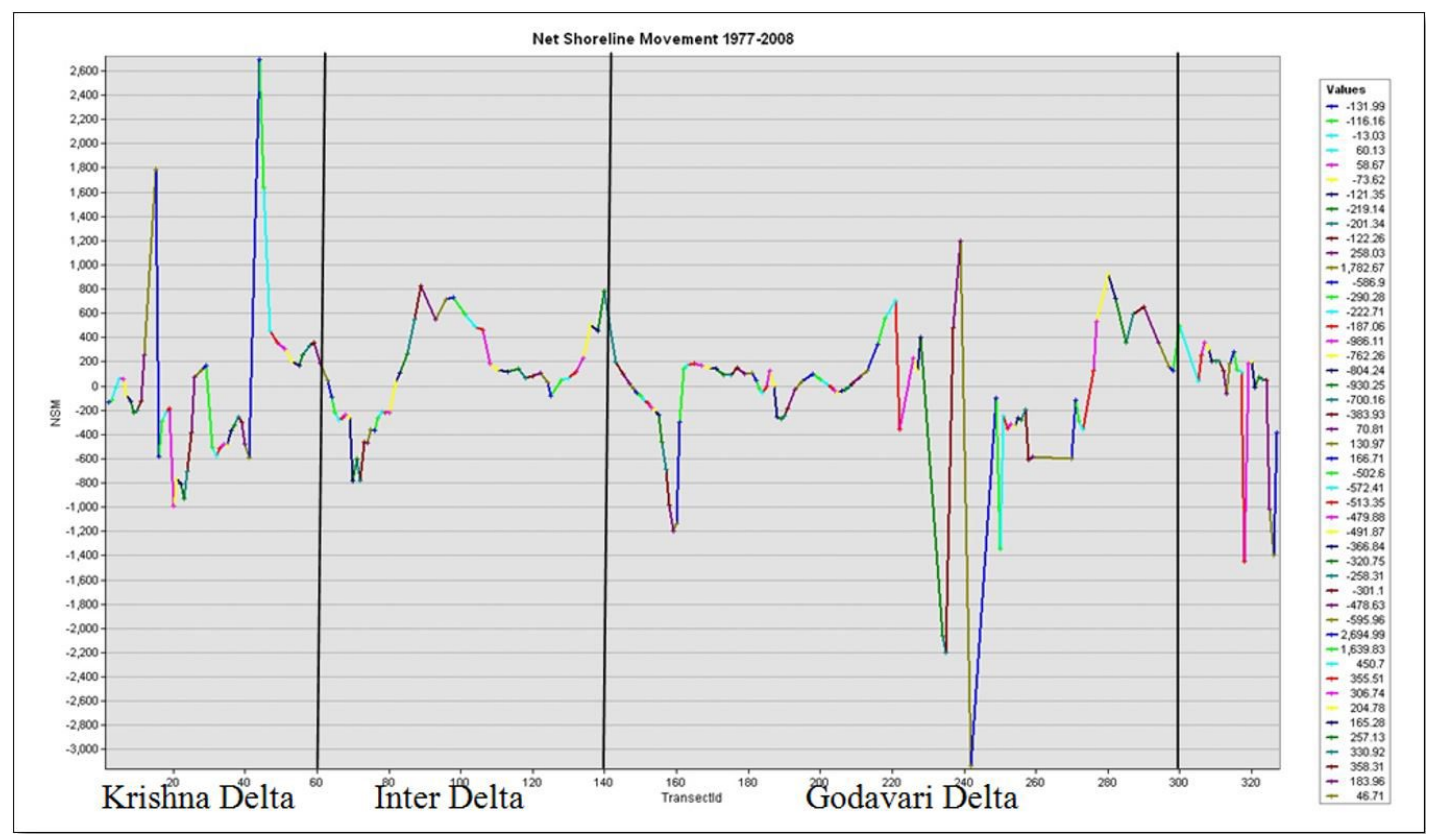

Figure 10. NSM/EPR Trend for K-G Delta (1977-2008)

Transects beyond 300 (Figure 10) were constructed to quantify the changes in the Kakinada Spit, a permanent feature of the Godavari delta. Estimating the EPR and plotting the trends of NSM to quantify the change occurring along the study area is vital to understand the degree of impact the sea is having on the delta, a formation created due to the delicate balance of sea and freshwater interactions. This understanding helps in accurately generating the Hazard Line along the coast, to the year 2050.

As indicated in Table 3, the EPR ranges from $-101.92 \mathrm{~m} / \mathrm{yr}$ to $87.62 \mathrm{~m} / \mathrm{yr}$ of erosion and deposition respectively. The net EPR indicates an erosion rate of $1.659 \mathrm{~m} /$ year. This indicates a permanent and ongoing erosion (or sea incursion) in the $\mathrm{K}-\mathrm{G}$ delta. As mentioned before, EPR is a point location estimate of occurrence of shoreline change. In order to quantify this, in terms of loss or gain of land, a polygon-based quantification of change between shorelines shows a loss of $73.007 \mathrm{~km}^{2}$ due to erosion and $30.904 \mathrm{~km}^{2}$ gained due to deposition. The net result of loss of $42.102 \mathrm{~km}^{2}$ during $1977-2008$ is in agreement with previous studies like Nageswara Rao et al., 2010 [11].

With the literature verified estimates of shoreline change in the region, the study now focusses on the main aspect of the post-DSAS workflow analysis; the construction of the Hazard line. The prediction of the future shoreline position is done, based on the rate of current trends and geomorphology [12]. Geomorphology maps generated by Nageswara Rao et al.., 2009 and assigned weights (Table 2) [12] were used to extrapolate a future hazard line (Figure 11). Some significant inferences from the future prediction involve the extended Spit, indicated in the Godavari delta and deposition in the inter-delta plain.

A further polygon-based GIS analysis of area indicates that a comparison between the predicted shoreline and 2008 position would result in an erosion of $121.968 \mathrm{~km}^{2}$ and deposition of $64.2922 \mathrm{~km}^{2}$; a net loss of $57.6758 \mathrm{~km}^{2}$.

\section{DISCUSSIONS}

End Point Rate (EPR) offered a vital insight into localised variations of erosion and deposition in the KrishnaGodavari delta. Encountering greater erosion, than deposition, this delicate equilibrium is in danger from the impacts of the sea and sea level rise. The change statistics have provided a time stamped assessment of the shoreline, the importance of which can be understood in both short and long-term trends. Short term trends provide an insight into local variations and events, while the latter provides a more normalised idea of the occurring phenomena. 


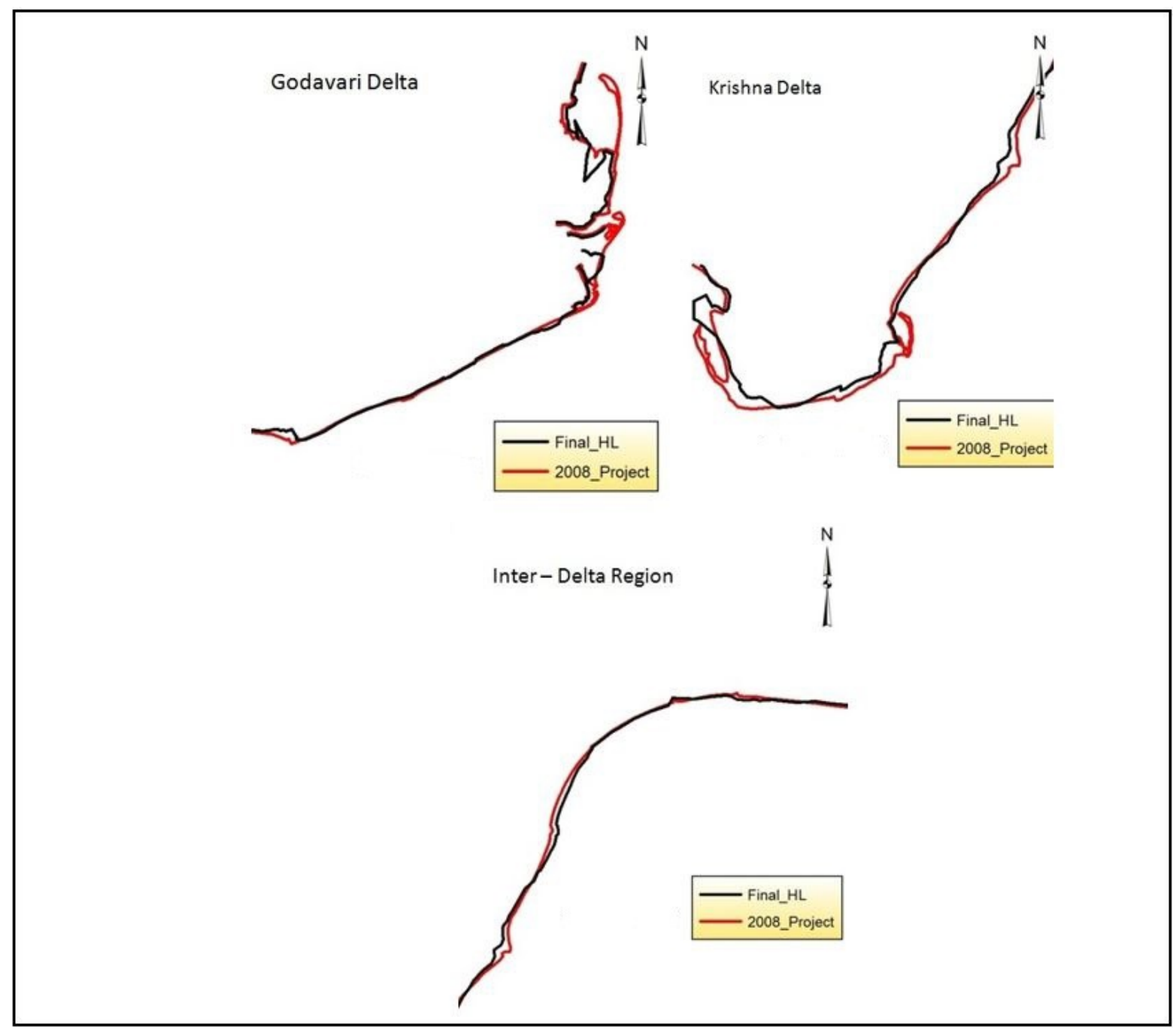

Figure 11. Comparison of coastline in 2008 and the predicted Hazard Line in 2050

The greater increase of erosion in datasets 2004-2006 indicated a direct implication of the tsunami, and how vulnerable the low-lying region of the K-G delta was to changes of sea level. Area lost in the region due to erosion from the sea, changes in sea level and construction of dams that block the sediments from reaching and replenishing the delta [11] is evident, and to the tune of $42.102 \mathrm{~km}^{2}$. Although deposition in the inter-delta region is evidence of along-shore movement of sediments, the equilibrium of this tectonically affected region is being disturbed. Following the predictions of the shoreline change to the year 2050, the region is in danger of losing an approximate $57.6758 \mathrm{~km}^{2}$. Local variations of tectonics, coupled with variations of temperature and global-scale changes, only increases the risk to the many inhabitants in the $\mathrm{K}-\mathrm{G}$ basin.

The changes (erosion and deposition) occurring in this region has been investigated, using change detection of shorelines, extracted from satellite imagery, spanning across 31 years. The general overall change is estimated during 1977 and 2008 (Figure 10, Table 3).

\section{CONCLUSION}

There are many conclusive aspects that can be drawn from this study. Short term trends indicated impacts of local phenomena, while long term trends calculated overall change, in agreement with previous studies [11]. 
The net change to the study area was due to erosion $\left(42.102 \mathrm{~km}^{2}\right)$ during the period of $1977-2008$. The hazard line (Figure 11) was demarcated using the trends of erosion/deposition and knowledge of geomorphology. Once established, a prediction of $57.6758 \mathrm{~km}^{2}$ loss of land due to erosion is made for the year 2050 .

\section{ACKNOWLEDGMENTS}

The author(s) would like to thank Prof Mark Richardson and Cranfield University for providing advice and financial assistance for completion and presentation of this paper at the SPIE Remote Sensing 2016 conference.

\section{REFERENCES}

[1] Church, J., Clark, P., Cazenave, A., Gregory, J., Jevrejeva, S., Levermann, A., Merrifield, M., Milne, G., Nerem, R., Nunn, P., Payne, A., Pfeffer, W., Stammer, D., and Unnikrishnan, A., [Sea Level Change], book section 13, 11371216, Cambridge University Press, Cambridge, United Kingdom and New York, NY, USA (2013).

[2] Gornitz, V., "Global coastal hazards from future sea level rise," Palaeogeography, Palaeoclimatology, Palaeoecology 89(4), 379-398 (1991).

[3] Meehl, G. A., Washington, W. M., Collins, W. D., Arblaster, J. M., Hu, A., Buja, L. E., Strand, W. G., and Teng, H., "How much more Global Warming and sea level rise?," Science 307(5716), 1769-1772 (2005).

[4] Soloman, S. D., Manning, Q. M., Chen, Z., and Miller, H. L., "IPCC (2007) Summary for Policymakers. Contribution of Working Group I to the Fourth Assessment Report of the Intergovernmental Panel on Climate Change," tech. rep., Cambridge University Press, Cambridge (2007).

[5] Vermeer, M. and Rahmstorf, S., "Global sea level linked to global temperature," Proceedings of the National Academy of Sciences, 21527-21532 (Dec. 2009).

[6] Hansen, J., Sato, M., Ruedy, R., Lo, K., Lea, D. W., and Medina-Elizade, M., "Global temperature change," Proceedings of the National Academy of Sciences 103(39), 14288-14293 (2006).

[7] To, D. V. and Thao, P. T. P., "A shoreline analysis using DSAS in Nam Dinh Coastal Area.," International Journal of Geoinformatics 4(1) (2008).

[8] Albuquerque, M., Espinoza, J., Teixeira, P., de Oliveira, A., Corrêa, I., and Calliari, L., "Erosion or coastal variability: An evaluation of the DSAS and the change polygon methods for the determination of erosive processes on sandy beaches," Journal of Coastal Research 65(sp2), 1710-1714 (2013).

[9] Kaliraj, S., Chandrasekar, N., and Magesh, N. S., "Impacts of wave energy and littoral currents on shoreline erosion/accretion along the south-west coast of Kanyakumari, Tamil Nadu using DSAS and geospatial technology," Environmental Earth Sciences 71(10), 4523-4542 (2014).

[10] Thieler, E. R., Himmelstoss, E. A., Zichichi, J. L., and Ergul, A., "Digital Shoreline Analysis System (DSAS) version 4.0 - An ArcGIS extension for calculating shoreline change," u.S. Geological Survey OpenFile Report 2008-1278, U. S. Geological Survey (2009).

[11] Nageswara Rao, K., Subraelu, P., Kumar, K. C. V., Demudu, G., Malini, B. H., Rajawat, A., et al., "Impacts of sediment retention by dams on delta shoreline recession: evidences from the Krishna and Godavari deltas, India," Earth Surface Processes and Landforms 35(7), 817-827 (2010).

[12] Nageswara Rao, K., Subraelu, P., Rao, T. V., Malini, B. H., Ratheesh, R., Bhattacharya, S., Rajawat, A., et al., "Sea-level rise and coastal vulnerability: an assessment of Andhra Pradesh coast, India through Remote sensing and GIS," Journal of Coastal Conservation 12(4), 195-207 (2008).

[13] Selvam, V., "Environmental classification of mangrove wetlands of India," Current Science 84(6), 757-765 (2003).

[14] Biggs, T., Gaur, A., Scott, C., Thenkabail, P., Gangadhara Rao, P., Gumma, M. K., Acharya, S., and Turral, H., [Closing of the Krishna Basin: Irrigation, streamflow depletion and macroscale hydrology], vol. 111, IWMI (2007).

[15] Manmohan, M., Rao, M., Kamaraju, A., and Yalamarty, S., "Origin and Occurrence of Lower Cretaceous High Gamma-High Resistivity (Raghavapuram) Shale - A Key Stratigraphic Sequence for Hydrocarbon Exploration in Krishna-Godavari Basin, AP," Geological Society of India 62(3), 271-289 (2003). 
[16] Prabhakar, K. and Zutshi, P., "Evolution of southern part of Indian east coast basins," Geological Society of India 41(3), 215-230 (1993).

[17] Nageswara Rao, K., "Evolution and dynamics of the Krishna delta, India," National Geographical Journal of India 31(1), 1-9 (1985).

[18] Nageswara Rao, K., Krishna, G. M., and Malini, B. H., "Kolleru lake is vanishing - A revelation through digital processing of IRS-1D LISS-III sensor data," Current Science 86(9), 1312 (2004). 